\title{
Facilitating en/counters with special education's cloak of benevolence in professional learning to eliminate racial disproportionality in special education
}

\author{
Kathleen A. K. Thorius
}

\begin{abstract}
Despite the U.S. government's funding and provision of technical assistance as a prevailing approach to remedy special education racial disproportionality, and considerable research on the explanations, causes, and frameworks for addressing the phenomenon, there is little documentation of research or technical assistance efforts for actually doing so. As a white, nondisabled professor and executive director of a federally funded Equity Assistance Center, I theorize and offer for critique ways I have facilitated (mostly white, non-disabled) educators' en/counters with culturally historically embedded systemic and individual practices contributing to the construction of special education as a cloak of benevolence for white supremacy and ableism. Drawing from a theory of expansive learning, I illustrate how purposeful introduction of artifacts into the activity system of a technical assistance relationship brings educators in contact with contradictions between their expressed goals of eliminating disproportionality and their pathologization of children's differences at the intersection of race and disability.
\end{abstract}

Keywords: Special education racial disproportionality, technical assistance, cultural historical activity theory, disability studies in education, race

This is the author's manuscript of the work published in final form as:

Thorius, K. A. K. (2019). Facilitating en/counters with special education's cloak of benevolence in professional learning to eliminate racial disproportionality in special education. International Journal of Qualitative Studies in Education, 32(3), 323-340. https://doi.org/10.1080/09518398.2019.1576945 


\section{Facilitating en/counters with special education's cloak of benevolence in professional learning to eliminate racial disproportionality in special education}

\section{What are the legacies of white supremacy and ableism doing in a benevolent place like special education?}

A few months ago while on sabbatical in a different state, I was invited for drinks with other mamas whose children were heading back to school the following day. I mostly sat and listened, and tried to connect with new women, mostly white, many educators. I sat across from a local elementary teacher and I mentioned that I had been a school psychologist in a nearby urban elementary district back in the early 2000s. She responded, 'Oh! My last principal was really amazing. But our school didn't really need him. He went to (urban) district where he could really make a difference. I could never work there. It'd be too hard. I'd want to take all the kids home with me!' The relevance of this exchange, which I have shared during professional learning I facilitate with educators toward addressing racial disproportionality in special education, lies in the commonplace reactions to educators who work in special education, or with youth with disabilities, or in urban schools, or with students with disabilities in urban schools are like this one: 'You must be so patient!' 'I could never do that!' 'How do you deal with the parents?'; the list is too long to include.

As this story illustrates, every day in schools across the U.S., educators construct student difference on the basis of imbricated and pathological notions of race and disability (Artiles, 2009; Ferri \& Connor, 2005; Thorius \& Waitoller, 2017; Waitoller \& Thorius, 2016), while simultaneously benefitting from views of themselves and perceptions by others that they are 
there to help. In other spaces, this particular mix of race/disability pathologization, along with systems of policing and construction of police as there to bring order, have great and negative consequences such as those powerfully captured by Talila A. Lewis (2017) in her broader condemnation of police violence at the intersection of: 'Race and Disability. The most dangerous intersection history has ever held. All that seems to exist there is violence, erasure and murder with impunity.' Arguably, these contexts are not the same - schools and streets - but as Annamma, Morrison \& Jackson (2014), and others have demonstrated, and the most recent US Civil Rights Data Collection supports, the school to prison nexus for students with disabilities, and specifically, students of color with disabilities is a phenomenon with a growing body of supporting research.

Accordingly, I aim to add complexity, and relatedly, tools, for eradicating violence and erasure in myriad forms of inequitable educational access, participation, and outcomes for students of color with disabilities/disability labels in U.S. schools, focusing specifically on racial disproportionality in special education, as perpetrated by white non-disabled educators including myself. By disproportionality, I mean the disproportionate representation of Black, Latinx, and Indigenous/American Indian students as disabled under special education eligibility categories that rely on educators' subjective judgement (e.g. Specific Learning Disability and Emotional Disturbance). Disproportionality refers as well to these same students' educational placements in segregated settings as rates far exceeding those of white peers with the same disability labels (Thorius \& Stephenson, 2012).

The highly charged topic of racial disproportionality in special education remains one of the most complex and entrenched issues in today's educational landscape, remaining immutable despite its debate as a construct and efforts to dismantle the phenomenon beginning in the 1960s 
(Graff \& Kozleski, 2014). For 50 years, well before the first rendition of the Individuals with Disabilities Education Act and continuing today, racial disproportionality in special education has been a deeply troubling, perfect storm of educational inequity: a storm in which racial bias leads to profiling black and brown students, placing them under surveillance that leads to biased assessments, labeling, and placements into segregated programs. These programs purportedly provide individualized education that should improve outcomes but, in fact lead to poor educational outcomes (e.g. 56\% graduation rate), segregation, and other discriminatory treatment. Simultaneously, some special education researchers have implied that of the characterization of disproportionality as discriminatory is an undeserved attack on special education itself (e.g. Kauffman \& Badar, 2013; Kauffman \& Hung, 2009). Their argument is that, after all, identification and placement decisions are based on educators' perceptions of student competence: what's so wrong with students getting what they need on the basis of their disability, and regardless of race?

Recently and along these lines, white researchers conducting disproportionality research concluded many students of color are under-identified for special education and, therefore, not getting what they need (Morgan et al., 2015). Subsequently, a group of well-regarded special education and educational civil rights scholars, many of whom are people of color, pushed back (Ford \& Toldson, 2015; Skiba, Artiles, Kozleski, Losen, \& Harry 2016; see also 2016 special issue of Multiple Voices for Ethnically Diverse Exceptional Learners) against this logic, critiquing recent studies on several grounds including flawed methodology, and failure to account for systemic discrimination and inadequate opportunities to learn for students of color. For the purposes of this paper, I frame the proposition that special education is what children of color and with disabilities need as opposed to educational systems that are set up for them to 
succeed as a cloak of benevolence enacted by white, non-disabled researchers and practitioners. This cloak allows racism and ableism to hide and for educators to benefit from and maintain identities as good and special white non-disabled helpers of 'exceptional' children of color, as suggested by this popular t-shirt message worn by many attendees at a 2015 national conference of special educators. Another popular t-shirt at the same meeting read, 'I am a special ed ninja!' (Figure 1).

\section{Special education as a cloak of benevolence}

I propose the notion of special education's cloak of benevolence as a useful theoretical tool for examining how education policy, systemic practices, and educators' beliefs and actions converge to maintain disproportionality at the intersection of student race and disability (Artiles, 2009). Specifically, the concept refers to non-disabled/white educators' socialization into and enactment of special education as a paternal, caring, protective, helping, and fixing field (Ferri, 2009; Ware, 2004) that is grounded in a medicalized knowledge base (Connor, 2013) and how underlying white and non-disabled supremacy inherent in such framings shape constructions of students of color with disabilities as deficient, abnormal, and incompetent (Annamma, Connor, \& Ferri, 2013; Oliver, 1996; Valencia, 1997). Simultaneously, the notion of special education as a cloak of benevolence positions the field and its educators as good, patient, and special, and as magicians, diagnosers, and fixers (Thorius, 2016a). Further, special education and its agents are the 'great white' non-disabled 'hope' (Green \& Dantly, 2013; Sackler, 1968) for students at disabled/raced intersections, providing them access to education - any education, not just a specialized one - is an improvement from those days before the enactment of the Education for All Handicapped Children Act of (1975).

\section{Connecting the cloak of benevolence to racial disproportionality in special education}


Just as the Civil Rights Act and Brown vs. Board of Education set in motion shifts in state and local education agency (LEA) practice to racially desegregate public schools, Public Law 94-142 of 1975 - now the Individuals with Disabilities Education Act - mandated a free and appropriate public education for students with disabilities. Yet, just as racial and socioeconomic segregation continue despite Brown and the Civil Rights Act, racial disproportionality in special education endures despite amendments to the Individuals with Disabilities Education Act in 1990, 1997, and 2004 in response to the researchers' calls to address the phenomenon. Critical scholars including some in the field of special education are unsurprised, asserting that top-down federal mandates contribute to technocratic local responses that de-center equity concerns (Kozleski \& Artiles, 2012).

With regard for disproportionality mandates, IDEA was amended in 2004 to prioritize regulations first introduced in 1997 that required states and LEAs to address disproportionate representation of racial/ethnic groups in special education. Over time, IDEA revisions toward addressing disproportionality have focused on remediating discriminatory special education referral and evaluation procedures, ensuring stronger protections and rights for parents in eligibility determination and placement decision processes, and states' monitoring and reporting by race and disability (McCall \& Skrtic, 2009).

In researching the relationship between policy and progress toward eliminating disproportionality, Albrecht, Skiba, Losen, Chung, and Middelberg (2012) analyzed State Education Agency (SEA) data required by the U. S. Department of Education, including the percentage of LEAs with significant disproportionality, and the percentage of LEAs reporting significant disproportionality as a result of inappropriate special education identification. The authors found that despite increases in thresholds triggering LEAs' designation as significantly 
disproportionate, the number of LEAs crossing higher thresholds increased as well. Further, LEAs reported to their SEAs that their disproportionality was not caused by inappropriate special education identification. As I reflect on the findings from this study, Ball's (2003) commentary about policy performativity in the absence of any real change in practice comes to mind. SEAs accounted for LEA disproportionality but loosened criteria for findings of any LEA as disproportionate and permitted LEAs to review their own data and provide their own rationales for higher rates of disproportionality.

Elsewhere, colleagues and have provided a theoretical frame and set of considerations for special education policy research that accounts for ways in which socio-historical and political forces, including racism, shape local policy appropriation (Thorius \& Maxcy, 2015; Thorius, Maxcy, Macey, \& Cox, 2014). In this instance, federal policy language allows white and/or non-disabled educators who appropriate disproportionality mandates locally to reason that disproportionate identification is 'not as a result of inappropriate practice' while concurrently treating student race and dis/ability as pathological differences to be remediated, fixed, or cured, reinforcing a 'key institutional function of special education in an unequal, stratified, and racialized education system' (McCall \& Skrtic, 2009, p. 3), but also the positioning of special education and its agents as a necessary good. In other words, this is an enactment of special education as a cloak of benevolence.

Within their reviews of existing disproportionality literature or theoretical framings of the subject, many scholars (e.g. Artiles, 2011; Sullivan \& Artiles, 2011; Voulgarides, Fergus, \& Thorius, 2017; Waitoller, Artiles, \& Cheney, 2010) have asserted the imperative of systemic efforts to remedy the issue. Some, particularly disability studies in education scholars have recommended approaches undergirded by models of disability as a social construction 
(Shakespeare, 2006) or social oppression (Erevelles, 2000) rather than the medical model that permeates educational systems (Oliver, 1996). This medical model frames disability as pathology and locates it 'beneath the skin and between the ears' of individual students (Mehan, 1996, p. 241). Other critical special education scholars have offered complex accounts for the ways in which race and ability have been intertwined (Annamma et al., 2013; Artiles, 2011; Thorius \& Tan, 2015). Yet, the complexity of such framings and recommendations has been unmatched by scholars' documentation of actual engagement in such efforts ${ }^{1}$. Moreover, in addition to a lack of research on everyday educational practices within local contexts that contribute to disproportionality as noted by Artiles (2011), methods for addressing disproportionality developed within technical assistance efforts (i.e. policy or practiceimprovement partnerships between state or federally funded agencies and local or state education agencies) (for example, see Kozleski \& Zion, 2006) remain unstudied in terms of the complexities or outcomes of engaging with such tools. It is in addressing the last of these issues toward which I turn the remainder of this work.

\section{Professional learning within technical assistance partnerships as a means to address disproportionality}

I am a white, non-disabled, heterosexual, cisgender woman who among my roles, serves as executive director for one of four educational Equity (formerly Desegregation) Assistance Centers funded by the U.S. Department of Education's Office of Elementary and Secondary Education. Formerly, while an Office of Special Education Program (OSEP)-funded fellow in a $\mathrm{PhD}$ program to prepare culturally responsive special education professors, I was a professional development coordinator for a national technical assistance and dissemination center, also OSEP funded, to eliminate racial disproportionality in special education. On these bases, often I am 
invited to provide remarks at district and state education department professional development forums in relation to a larger technical assistance relationship between my EAC and a K-12 public educational agency. At times, I am asked by state officials to present a set of 'high leverage strategies' and technical solutions (Thorius, 2015) for addressing disproportionality: step-by-step approaches educators can enact in the here and now, and which over time I have come to understand as surface actions that leave systemic inequities unchanged or simply shift them to new manifestations such as school push-out. As is supported by the (scant) research on educational technical assistance, these types of strategy-seeking requests are all too common in the absence of deep and critical reflection on equity (Kozleski \& Artiles, 2012, 2015; Thorius et al., 2018) including systemic and personal acts of racism, ableism and accompanying discrimination.

At these types of forums, I have observed sessions wherein educators are asked by professional learning facilitators to consider race, yet the concepts and activities introduced to them are glancing blows easily shaken off by the collective imaginary of white, non-disabled superiority. For example, over the last few years while waiting for or following my own sessions, I have observed several keynote and break-out sessions on implicit bias delivered to auditoriums full of mostly white and a relative few Black, Asian, Native, and Latinx educators. A typical opening goes something like this: an invited speaker introduces participants to the definition of implicit bias, and at some point guides them through snippets of Harvard's Project Implicit Bias Test or a parallel adaptation. The appeal of this approach, I have come to conclude, lies not only in its tidy conceptual packaging and the propensity many of us have to take the click bait of an online quiz, but because over time and through close observation I have seen how white people in the room are able to maintain not only their identities as good, non-racist individuals but also their 
comfort; after all, as the one hour session typically concludes, 'everyone is biased,' not just white people. And as the term implicit implies, it's not my fault. That is, the historical legacies of white supremacy and ableism, and the ways in which educators re-inscribe and reenact these legacies presently, are left intact.

Over time and with much gratitude to the mix of loving and direct critique from family, colleagues, and friends of color and with disabilities, I have learned that a function of my white non-disabled privilege was the belief that I could engage in race and disability justice work across spaces and groups, with few exceptions. Moreover, I have been taught that my primary purview is to engage in anti-racist, anti-ableist work with non-disabled white people like me, and with the same accompanying intersectional privilege. And learning from critical and sociocultural learning theorists from the fields of disability studies in education, critical race theory, and cultural historical activity theory (CHAT), that my technical assistance work is to confront and redress two historical legacies contributing to racial disproportionality in special education (and other violence against students of color/with disabilities) with and that people like me have engaged for centuries and continue to reproduce: our roles as oppressors with positions of superiority and roles of appraisal within intersecting systems of white supremacy and ableism.

In the remainder of this paper, I sketch out this work, framing it not as exemplary, but as the beginning of an incomplete offering for critique as a messy, imperfect example of ways I have facilitated educators' en/counters with the intersectional roles of white supremacy and ableism in special education disproportionality. I provide examples aimed at en/countering prevailing and raced notions of intelligence and medical models of disability to contribute to broader 'strategic coalitions toward inclusive education and against exclusion' at the intersections of race and disability (Thorius \& Waitoller, 2017, p. 252) and as part of 'longer and much broader 
movements of cultural and educational justice,' (Paris, in Alim et al., 2017, p. 11). More specifically, through these en/counters, I attempt to introduce and engage educators in critically examining special education's cloak of benevolence, and relatedly, ways in which they construct their roles and responsibilities vis-à-vis positioning students of color/with disabilities as different and simultaneously re-inscribing white supremacy and non-disabled (i.e. intellectual, physical, and moral) superiority. In this way, I frame professional learning efforts to address special education disproportionality as work to 'denaturalize whiteness, normalcy, and the legacies of colonization; it is a convergence for various efforts that aim to reform exclusionary notions and practices that reify ideologies expressed in 'regular' education and the construction of the 'normal child' (Thorius \& Waitoller, 2017, p. 253; Baglieri et al., 2011).

\section{Applying cultural historical activity theory as a frame for professional learning that} addresses disproportionality

In recognition of the importance of theory and its frequent absence in special education (Artiles, 1998) and technical assistance literature (Kozleski \& Artiles, 2012), I rely on CHAT as a frame for organizing professional learning toward the objects and outcomes I described above. Within this frame, I draw conceptual tools from disability studies (in education), critical special education, and critical race theory to plan and facilitate professional learning experiences within larger technical assistance projects with state and LEAs, within my Equity Assistance Center work.

Addressing disproportionality at the intersections of the technical and atheoretical histories of professional development (Thorius \& Scribner, 2013) and the positivist traditions of special education research (Kroesbergen \& Van Luit, 2003), requires theory that accounts for the cultural and historical nature of this issue. With relevance for understanding the inadequacy of 
professional development focused on educators' learning of stock technical solutions to special education disproportionality, Engeström rejects the notion of a competent 'teacher' who knows what is to be learned on the grounds that 'much of the most intriguing kinds of learning in work organizations violates this presupposition.' He continues:

People and organizations are all the time learning something that is not stable, not even defined or understood ahead of time. In important transformations of our personal lives and organizational practices, we must learn new forms of activity which are not yet there. They are literally learned as they are being created. There is no competent teacher. Standard learning theories have little to offer if one wants to understand these processes. (Engeström, 2001, pp. 137-138)

\section{Expansive learning}

On these bases, I draw from Engeström's notion of expansive learning (Engeström, 1987) situated within CHAT's potential to open 'new ways of theorizing phenomena that emphasize relations and histories' (Roth, 2012, p. 101) in the context of white supremacy and ableism. CHAT and expansive learning rest on the notion that development occurs through goal-oriented and tool-mediated cultural practices (Engeström \& Sannino, 2010). The theory of expansive learning consists of seven steps undertaken by participants (i.e. subjects) of an activity system and facilitated by researchers, which I outline briefly, below:

In step one, participants engage in contextual analysis of their current context and practices therein, with an emphasis on problematic situations, systemic and historical forces that have contributed to these problems. Step two is geared toward uncovering and evoking contradictions and tensions within the systemic structure of the activities contributing to the problem. In step 
three, participants work on transforming this problematic systemic structure toward an expansive way of resolving the contradictions within it. Step four is about expanding the purpose, or object of the activity system through determining new model of activity. In step five, participants implement this new model of activity, while solidifying and testing out the innovations by putting first steps into action while developing and implementing new tools for doing so. Finally, steps six and seven involve reflecting on the implementation of this new model of activity, building into it processes and efficiencies, and then disseminating the new model throughout connected activity systems (Engeström, 1987) (Figure 2).

In what follows, I focus on the process of expansive learning I work to facilitate through professional learning meant to contribute to eliminating special education disproportionality. I note efforts to illustrate each step of an expansive learning cycle, yet emphasize my deliberate introduction of primary stimulus artifacts into the professional learning relationship activity system and which stimulate participants' en/counters (Tan \& Thorius, 2018a; Thorius et al., 2018) with special education's cloak of benevolence as a powerful contradiction in relation to step two of an expansive learning cycle. Over time, and mediated by my introduction of secondary stimulus artifacts in the form of potential tools to be appropriated in resolving this contradiction stimulates educators' development of new activity models for addressing disproportionality. I illustrate in a forthcoming manuscript co-authored with administrators of a state department of education who describe and analyze their shifting local practices (Thorius et al., 2018): steps five through seven of the expansive learning cycle related to the current work.

\section{Facilitating en/counters with white supremacy and ableism at the foundation of systemic practices of (special) education}


Pervasive and systemic sorting and classifying practices of schooling occur on the basis of dominant norms about the construction and treatment of difference in relation to student race and disability. I illustrate how educators' TA provider-facilitated mapping of current systemic practices are mediated through the introduction of the idea that certain systemic practices contributing to disproportionality reflect historically inbricated notions of white supremacy and ableism (Erevelles, 2014), along with the ways in which educators grapple with contradictions posed by this stimulus: first and second steps of a cycle of expansive learning toward eliminating racial disproportionality in special education.

\section{En/counters with the residue of eugenics in the sorting of students by race and ability}

Educators' beliefs and practices are shaped by powerful historical and social forces of white supremacy and ableism that coalesce within education systems (Annamma et al, 2014; Connor \& Ferri, 2005). On this basis, one of my aims within technical assistance partnerships is to facilitate professional learning experiences within which educators en/counter ways systemic practices of sorting children on the basis of dominant ideas about intelligence and normalcy - indeed, special education - are sticky with the residue of the eugenics movement.

Recently, Leroy F. Moore, Jr a Black disabled musician, artist, and activist turned his performance piece, Black Disabled Art History, into a children's book with the same name (2016). Moore includes images and descriptions of Black disabled artists' work, and of them working, in his efforts to redress violence against Black disabled people by and their erasure from media and society. With gratitude and credit to Moore and other disability activists and scholars, I introduce into the activity system of a professional learning partnership the artifacts of eugenics and related intersectional consequences of racism and ableism to en/counter white, nondisabled educators' establishment, maintenance, and reproduction of practices that situate 
themselves as racially, intellectually, and morally superior to students of color/with disabilities. What is unfortunate, but not surprising, however, is that most white non-disabled educators know little about this history, and even less have taken the opportunity to connect current (their own and systemic) educational practices with such legacies, making this an important aspect of professional learning approaches to address disproportionality. This new knowledge is a disruption - a contradiction - to their belief in possibility of objectivity when it comes to determining students' competence, and accordingly, their treatment of student difference at the intersection of race and dis/ability. In other words, participants experience the contradiction that one cannot be committed to eliminating disproportionality and participate in racist/ableist systemic practices.

One process through which I have begun such en/counters within professional learning interactions is to pose to educators and then ask them to turn and briefly share with a peer: 'based on your own history, as well as your preparation and experience as an educator, in what ways do you define “disability”?' With those definitions and discussions fresh in peoples' minds, I introduce an idea well-developed by disability studies scholars to facilitate educators' en/counter with the medical model of disability upon which special education relies; that is, the myth that human behavior or intelligence distributes along the lines of a bell-shaped, normal curve. At a recent session, I facilitated with several hundred school psychologists, it was no coincidence what they just received as a freebie from their professional organization upon entering the room: a laminated bell curve made by a psychological testing company to promote their products and for these professionals to use in their assessment practices. As they literally sat with this contradiction on the tables in front of them, I read from Dudley-Marling and Gurn's (2010) Myth of the Normal Curve: 
A considerable body of research has demonstrated that the normal curve grossly misrepresents the human experience... The normal curve was discovered by de Moivre as the mathematical expression of the limiting case of a binomial distribution for chance events such as flipping a coin, not socially mediated human behaviors, which are influenced by various social, economic, and cultural factors, and therefore, do not distribute normally. (Goertzel \& Fashing, 1981, pp. 10, 266)

Then, I read from the quotes Dudley-Marling and Gurn included in their own work, from a slide like the one pictured in Figure 3 (Thorius, 2017), and which contributed to Dudley-Marling and Gurn's assertion that 'the hegemony of the normal curve has had a devastating effect on those presumed to live on the boundaries of normal' (p. 266).

Relatedly, I have come to consider important within the purposeful facilitation of educators' en/counters with the legacies of eugenics, opportunities for them to connect eugenics-era practices to current systemic approaches to sorting and classifying students on the basis of norms and measures of intelligence, and with disproportionately negative impact on students of color/with disabilities. As one example, we consider systemic reliance on IQ tests despite their role in the disproportionate identification of students of color for special education: IQ tests that rely on a normal distribution of human intelligence and which are grounded in the work of were originally developed by - eugenicists. Galton's eugenics movement during the late $1800 \mathrm{~s}$ and early 1900s was characterized by the ideas that race, intelligence, and a likelihood of menacing and criminal behavior were all intimately related, and that one could improve the human race by careful selection of those who mate and reproduce. One set of artifacts I introduce to stimulate this en/counter is to show images of signs posted at eugenics-era state fairs (which I use under non-commercial educational use only copyright permission from the American 
Philosophical Society), including one which reads 'Every 50 seconds a person is committed to jail in the United States. Very few normal people go to jail.' On another, we read, 'Every 15 seconds, $\$ 100$ of your money goes for the care of persons with bad heredity such as the insane feeble-minded criminals and other defectives.' Or, we look at a picture of a Better Baby Competition at the Indiana State Fair, from the collection of the Indiana Eugenics Library, in which young white children, unclothed except for draped white sheets, are being measured and otherwise assessed by white female examiners. I read from a real 'Better Babies Diploma' before examining side by side, a picture captioned with 'feeble-minded in a cripple school', a segregated Mexican School in New Mexico circa 1935, and a picture of a special education selfcontained classroom full of children of color.

This is to certify that we have conferred on Donald Workman first prize in division 1 at the Better Babies Contest for attaining an average score of 99 percentum in physical and mental development as measured by the better babies standard score card on August 30, 1918. (Workman, 1918)

'In what ways do our current practices and systems reflect these troubling historical legacies?' I ask. And sometimes tentatively, sometimes forcefully, educators begin to answer. Through these ethnographic analyses, participants begin to reveal and simulate the inner contradictions of the systemic structure of activities causing disproportionality. Educators begin to assess disproportionality in terms of the enforcement of normalcy and in the form of white, nondisabled status. This evidence of expansive learning provides context for my introduction of a secondary stimulus to re-mediate the objects of educators' work who are committed to addressing racial disproportionality in special education. These stimuli include artifacts such as Waitoller and Kozleski's (2013) definition of inclusive education grounded in Nancy Fraser's 
(2008) theorizing of social justice, deeper examination of the medical model of disability in juxtaposition with cultural (Brown, 2002) and social models (Shakespeare, 2006), tenets of critical race theory (Delgado \& Stefancic, 2017) and more recently, disability critical race theory (Annamma et al., 2013).

\section{En/counters with 'corroborating stories' of white racism/and non-disabled ableism in everyday practice}

In recognition of the importance of counter stories (Delgado, 1989) in critical race scholarly praxis, but mindful of the dangers of white scholars' potential to claim CRT 'as a form of colonization in which we would take over CRT to promote our own interests or recenter our positions while attempting to 'represent' people of color' (Bergerson, 2003, p. 52), I introduce to educators the notion of 'corroborating stories'. Corroborating stories clearly and critically illustrate the ways in which ableism and racism, undergirded by white supremacy, have played out in my own systemically embedded practice. As is the case with historical legacies of eugenics in special education systemic practice, my corroborating stories serve as primary stimulus which mediate participants' mapping of their own systemic practices in order to en/counter the contradictions inherent in their corroboration with racist/ableist practices.

In attempt to avoid co-opting CRT as a white scholar, unlike 'counter stories', corroborating stories focus the participants' gaze onto me as a white, non-disabled object of critique. Below, I share a corroborating story I introduce within certain professional learning experiences; among many themes, this story demonstrates the de-legitimization of Spanish/bilingualism as a measure of students' ability and maintains smartness as the property (Leonardo \& Broderick, 2011) of white, U.S.-born students (names and certain details in the story are changed to protect student and educator anonymity). 
In 1999, fresh out of graduate school on the east coast where I had worked in a city high school, and where the majority of students were Black, I made the move to a new school in the Southwestern U.S., where almost $90 \%$ of the students were Latinx, and about half were Mexican immigrants, many undocumented. The Spanish I learned from 7 th to 12 th grade and one college semester was grossly inadequate. Of the eight psychologists in the district, NONE of us spoke Spanish fluently. Yet, I was the only psychologist in a school of 1500 students where about $15 \%$ of the students had identified disabilities. This school, like almost all others in the district, had one self-contained classroom where students primarily labeled with mild mental retardation (the label de jure) spent more than $80 \%$ of their school day. Early on, the teacher of this classroom, (also a white, non-disabled first year professional) and I sat down to familiarize ourselves with the ten students' IEPs, present levels of educational performance, education goals, and dates for what we short-handed as ' 3 year re-evals'. The first student up for reconsideration of special education eligibility was a seventh grader: José. José and his family spoke Spanish as their home language and were immigrants from Mexico when he was 4 years old. José had been identified for special education in first grade under the category of mild mental retardation and placed in a self-contained classroom where he had been educated ever since. This was José's third school campus in six years, because the district had a history of moving self-contained classrooms from school to school as total district enrollment increased. When it came time to review his file more closely, I began with the former school psychologist's psychoeducational evaluation report and my stomach soon dropped. José had been assessed using the English-language version of the Wechsler Intelligence Scale for Children, in first grade. His teacher also had completed a Vineland Adaptive Behavior Scale as the second required measurement for determining eligibility under the MIMR category. On both measures, José received a score just under two 
standard deviations from the mean standard scores. I quickly thumbed through the rest of the report looking for evidence of classroom observations, family interview and developmental history data, anything to support the decision to label José with Mild Mental Retardation. I found brief mentions with few details. The original concern was that José was not learning his letter sounds as quickly as his peers, that he was often silent in class, and that he sometimes appeared confused when the teacher provided instructions, relying too much on his peers for assistance. Ok, I reassured myself, let me take a look at the three year reevaluation from 4 th grade. When I looked, all I found was a brief report and signature page that the team had determined no new assessments were needed to determine José's continuing eligibility for special education under his current category, or to determine the appropriateness of his educational placement. No new assessments were needed for a now 7th grade young man who had been labeled since he was 6 , relying solely on an assessment administered in English, and an adaptive measure completed by his teacher. All I could do, I thought, was reconvene the team and recommend additional assessment, this time in both English and Spanish, and ask Jose's mother to complete the Spanish version of the Vineland. Jose scored in the so-called average range on both. Now the team was faced with exiting from special education a 7th grader who had been in a selfcontained classroom since he started school, or my suggestion, reclassifying José under the eligibility category of LD on the basis of a significant discrepancy between his IQ score and his academic achievement, but ignoring the 'educational disadvantage' clause meant to rule out student eligibility as a result of not being taught, but still having to decide about him remaining in the self-contained classroom or re-enter general education for over $80 \%$ of his day where he would switch classrooms and teachers for all his content areas. 
I share my corroborating stories to create ways for participants to simultaneously recognize in themselves from the actions and statements of those in the stories, followed by a set of questions in which educators are asked to think and talk together about what these stories reveal about the individual and systemic belief systems and practices within which they played out-moving them intentionally toward critical recognition and reflection on manifestations of racism and ableism in their own practice. In this way, participants once again ethnographically map and analyze their own systems. Participants draw from the previous discussion on eugenics and race/disability constructions as they consider questions like these to critique my actions before developing questions upon which I ask them to reflect in relation to authorship of their own corroborating stories: What and whose assumptions about intelligence, language, race, and immigrant families informed what happened to José? What and whose procedures contributed to what happened to José? In what ways did practitioners benefit from what happened to José?

Next, I engage participants in a journaling activity in which I ask participants to document their own corroborating stories, not to be shared with others but as an effort toward recognizing our/their own participation in systemically racist and ableist acts and consequences. Throughout these exercises, I am mindful of Artiles's (2009) assertion that special education referral decisions (along with other eligibility determination practices) must be examined in the contexts of cultural practices of schooling and 'of the schools within which these decisions are made, along with the context of educators' personal and 'cultural beliefs about competence and performance' (p. 26).

As examples of secondary stimuli I introduce and which illustrate steps three and four of an expansive learning cycle, I introduce another round of artifacts into the activity system. In the form of processes that have potential to mediate systemic change toward inclusive education 
through the redistribution of educational resources, recognition of students' collective and individualized experiences in relation to race, disability, and other marginalized statues, as well as representation of those same students and their families in education decisions and emphasize their experiences of past injustices within education systems (Waitoller \& Kozleski, 2013). Such artifacts include a detailed planning rubric regarding the ways in which schools set up their multi-tiered systems of support (MTSS) processes (Thorius, 2016b), along with questions for facilitators of schoolwide academic and data review aims to shift educators' attention and discussion from concerns with students' 'troubling' behavior toward the cultural practices of adult educators within the school that contribute to troubling systemic practices (Thorius, 2015). Educators analyze, critique, and refine these tools both within the professional learning interaction itself, as they begin planning new forms of activity to resolve previously identified contradictions in their systemic practices: a new activity model toward addressing disproportionality back in their local contexts (i.e. steps five through seven of the expansive learning cycle).

\section{Facilitating en/counters with white supremacy and ableism in educators' beliefs about themselves and their students}

Educators' roles are grounded in histories of participation that place us in powerful positions of expertise and appraisal in relation to students more generally, and to students of color/with disabilities more specifically. Part of my work in addressing disproportionality through facilitated professional learning is toward educators' en/counters with the power they have and have constructed for themselves in relation to their students, starting with how they conceptualize their roles and responsibilities with them. These en/counters no longer allow 
special educators to hide under a cloak of benevolence, and instead reveal contradictions in their beliefs about the worth and competence of all children.

\section{En/counters with the figured worlds of white, non-disabled teachers of children of color/with disabilities}

Before (white, non-disabled) educators, including former school psychologists like me, ever entered our roles, there existed ideas about what educators who work with students of color/with disabilities are supposed to value, believe, and do; such ideas shape decisions to enter into the field and notions of one's beliefs about and performance of one's role in relation to children with whom we work. The story I shared in my opening paragraph illustrates some of these ideas and their impact. This story illustrates Holland and colleagues' construct of a figured world that I have applied elsewhere (Thorius, 2016a) in a study to examine how white, non-disabled educators constructed themselves and their roles. Figured worlds are 'socially and culturally constructed realm[s] of interpretation in which particular characters and actors are recognized, significance is assigned to certain acts, and particular outcomes are valued over others' (Holland et al., 1998, p. 52). Within them, people figure cognitively and procedurally their identities through participating in activities and social relationships.

Within the professional learning community I convened as part of the aforementioned study (see also Tan \& Thorius, 2018a, 2018b), we focused on inclusive mathematics education for students with disabilities and where many students were of color and educated in self-contained classroom settings. Educators described their cognitive figuring of themselves as patient and expert helpers on the basis of their knowledge of the relationship between students' disability labels and skill-deficits. Procedurally, they described their roles as magicians, fixers, remediators, diagnosticians, and hole-fillers. Within the context of professional learning, 
specifically aimed at addressing disproportionality, I ask participants to reflect on others' reactions upon sharing they are an urban educator, a special education teacher, or work with children of color and/or with disabilities. On large post-its attached to walls around the room, they reflect the tropes of patience, sainthood, and missionary work. I introduce the primary stimulus of data from my 2016 study to illustrate ways we educators view ourselves as superior to our students, in relation to race, disability, or both. Along with the educators' post-it documentations, these examples mediate their en/counters with the social forces of white supremacy and ableism present in educators figuring of themselves. We generate more examples: gatekeeper, advisor, interventionist - all of which evoke the contradiction inherent in benevolent identities that assume superiority in relation to the benevolent and inferiority in relation to the beneficiary. To further stimulate the tension, I pose a secondary stimulus: in what ways might we re-configure our roles and responsibilities toward

(a) the redistribution of quality opportunities to learn and participate in educational programs...(b) the recognition and value of differences as reflected in content, pedagogy, and assessment tools,... and (c) the opportunities for marginalized groups to represent themselves in decision-making processes that advance and define claims of exclusion and the respective solutions that affect their children's educational futures.... (Waitoller \& Kozleski, 2013, p. 35)

\section{En/counters with educators' discourse about students of color/with disabilities}

The following appeared on the refrigerator of the teachers' lounge in which myself and colleagues conducted a year-long study into the practices of elementary urban educators engaging in meetings about students about whom they had academic or behavioral concerns: 
FYI. Rating teachers on the basis of pupil progress is foolish and unfair in the cases of kids who never get cognitive training in poor homes. No matter how good the first grade teacher, teaching essentially falls on deaf ears. There can be no progress when there is not much to start with. So you can congratulate, in advance, teachers of kids from educated homes and say 'tough luck' to the ones who deal with products of ignorant homes. How about cognitive preschool for them? As the twig is bent, so grows the tree.' (Thorius et al., 2014, p. 8)

I reproduce this quote, along with its large red-fonted title 'FYI', and explain how these meetings were often attended by the very same parents to whom this quote tacitly referred. This serves as a primary stimulus to mediate educators' en/counters with ways in which their discourse about students of color/with disabilities reflect, again, the cloak of benevolence under which they and their systemically embedded practices have been obscured. Sometimes, I provide scripts from data I have collected as part of the above and other studies in which educators discuss their students of color/with disabilities, and ask educators to role-play and then reflect on the text and their emotional reactions. In some instances, at a later date, I am invited as a participant observer of educators' discussion of their concerns about students' progress within local MTSS (i.e. Response to Intervention, National Center on Response to Intervention, 2010) meetings. As part of this ongoing cycle of expansive learning, I offer my reflections on their discourse as a critical friend, moving into the cycle's steps five through seven. In the context of a single professional learning event, however, I might introduce a secondary stimulus of a facilitation guide for leaders of MTSS meetings that focus exclusively on students' successes, descriptions of contexts in which students feel good and do well, discussion of students' cultural and linguistic repertories of practice (Gutiérrez \& Rogoff, 2003) and focus on the development of responses to students' learning that build upon these three. Alternatively or concurrently, I introduce a 
dialogue guide shaped by the technical, contextual, and critical domains of practice to be addressed through a culturally responsive cognitive coaching (Mulligan \& Kozleski, 2009) relationship, and that draws from a cross-pollination of culturally sustaining pedagogy (Paris, 2012) and universal design for learning (CAST, 2011; Thorius \& Waitoller, 2017; Waitoller \& Thorius, 2016). Mediated by these secondary stimulus, educators begin to engage and reflect on the appropriation and innovative use of these artifacts in their local contexts and my ongoing relationship with them centers these processes.

\section{The incomplete cycle and the never-ending work}

In this paper, I have shared my work facilitating professional and expansive learning toward eliminating disproportionality as a white, non-disabled technical assistance provider and faculty researcher. In doing so, I am committed to addressing my own and collective role in racist/ableist practices that undergird special education, while attempting to avoid re-centering whiteness (Leonardo, 2010) and non-disabled-ness.

The approaches I have begun to outline simultaneously move away from technical assistance and/or professional learning as an atheoretical and purely technical endeavor (Kozleski \& Artiles, 2012; Thorius, Maxcy, \& Nguyen, 2015). Instead, activities framed within a cycle of expansive learning stimulate educators' en/counters (Tan \& Thorius, 2018a) with residue of eugenics in current practices undergirding special education, along with special education's cloak of benevolence as the objects of critique and as contradictions that must be resolved through new objects of and activity models related to eliminating disproportionality. Concurrently, activities include the generation and critique of corroborating stories that draw from questions like those I shared in connection with my own work with José (e.g. What and whose assumptions about intelligence, language, race, and immigrant families contribute to these 
stories?). In other words, efforts to remediate disproportionality through TA and related professional learning must intentionally facilitate educators' en/counters with ways in which their identification of students of color as disabled are grounded in positioning students of color/with disabilities as different on the basis of pathology and deviance, and upon underlying notions of white, non-disabled educators' own superiority. I reiterate that my efforts, too, are ripe for critique.

Although I have focused primarily on white, non-disabled professional learning participants, it is important to restate that it is not uncommon that there are a few people of color who are also part of the experiences I have described. There is evidence that disability is a difference that remains constructed from a medical model not only in white communities, but also in otherwise critical communities of color (Erevelles, 2014). Yet, so as not to equate the belief systems of nondisabled white and biracial, indigenous, people of color, when working with inter-racial groups we compose the technical assistance team of at least two individuals wherein one is white and the other is a person of color and include parallel but notably different activities engaged by educators of color. However, even when participating in the kinds of activities like those I have described above, we have received anonymous and direct feedback from people of color a recognition of the need for such direct and unavoidable confrontation of racism (see Skelton, 2019, this volume). Simultaneously, within our own center, white staff and faculty engage in ongoing white affinity group meetings in which we continue to interrogate the manifestations of whiteness, racism, and ableism in our intra-center and outside TA work.

Finally, expansive learning offers a particularly useful approach for organizing these efforts due to a recognition that learning is never complete; expansive learning cycles remain necessary as systems and those with dominant positions within them fight to maintain stasis, inequities will 
emerge as other systemic practices. This tendency requires that expansive learning cycles related to remediating disproportionality position educators as 'cultural vigilantes (Corbett \& Slee, 2000, p. 134) who pay continuous attention to how new margins and centers are produced in contexts that are in constant flux (Artiles \& Kozleski, 2007)' (Waitoller \& Kozleski, 2013, p. 27), with particular attention to their own role in their creation and dismantling.

Notes: For a set of scholarly works related to systemic efforts to address disproportionate discipline of students of color see Bal, Kozleski, Schrader, Rodriguez, and Pelton (2014), Bal, Schrader, Afacan, and Mawene (2016) and Voulgarides, Fergus, and Thorius (2017).

\section{Disclosure statement}

No potential conflict of interest was reported by the author.

\section{Notes on contributor}

Dr Kathleen A. K. Thorius is an associate professor of special education in Indiana University's School of Education at IUPUI and executive director for the Great Lakes Equity Center and its Midwest and Plaines Equity Assistance Center, funded by the US Department of Education to address school desegregation in relation to race, gender, and national origin. Dr Thorius has a strong record of facilitating partnerships with state departments of education and school districts to create inclusive educational systems. 


\section{References}

Alim, H. S., Baglieri, S., Ladson-Billings, G., Paris, D., Rose, D. H., \& Valente, J. M. (2017).

Responding to "cross-pollinating culturally sustaining pedagogy and universal design for learning: Toward an inclusive pedagogy that accounts for dis/ability". Harvard Educational Review, 87(1), 4-25. doi:10.17763/1943-5045-86.3.366

Albrecht, S. F., Skiba, R. J., Losen, D. J., Chung, C.-G., \& Middelberg, L. (2012). Federal policy on disproportionality in special education: Is it moving us forward? Journal of Disability Policy Studies, 23(1), 14-25. doi:10.1177/1044207311407917

Annamma, S. A., Connor, D., \& Ferri, B. (2013). Dis/ability critical race studies (DisCrit): Theorizing at the intersections of race and dis/ability. Race, Ethnicity and Education, 16(1), 131. doi:10.1080/13613324.2012.730511

Annamma, S. A., Morrison, D., \& Jackson, D. (2014). Disproportionality fills the gaps: Connections between achievement, discipline and special education in the school-to-prison pipeline. Berkeley Review of Education, 5(1), 53-87. Retrieved from https://doiorg.proxy.ulib.uits.iu.edu/10.5070/b85110003

Artiles, A. (2009). Re-framing disproportionality research: Outline of a cultural-historical paradigm. Multiple Voices for Ethnically Diverse Exceptional Learners, 11(2), 24-37.

Artiles, A. J. (1998). The dilemma of difference: Enriching the disproportionality discourse with theory and context. The Journal of Special Education, 32(1), 32-36.

doi:10.1177/002246699803200105 
Artiles, A. J. (2011). Toward an interdisciplinary understanding of educational equity and difference: The case of the racialization of ability. Educational Researcher, 40(9), 431-445. doi:10.3102/0013189X11429391

Artiles, A. J., \& Kozleski, E. B. (2007). Beyond convictions: Interrogating culture, history, and power in inclusive education. Journal of Language Arts, 84(4), 351-358.

Baglieri, S., Bejoian, L. M., Broderick, A. A., Connor, D. J., \& Valle, J. (2011). [Re]Claiming inclusive education toward cohesion in educational reform: Disability studies unravels the myth of the normal child. Teachers College Record, 113, 2122-2154.

Bal, A., Kozleski, E. B., Schrader, E. M., Rodriguez, E. M., \& Pelton, S. (2014). Systemic transformation in school: Using Learning Lab to design culturally responsive schoolwide positive behavioral supports. Remedial and Special Education, 35(6), 327-339. doi:10.1177/0741932514536995

Bal, A., Schrader, E. M., Afacan, K., \& Mawene, D. (2016). Using learning labs for culturally responsive positive behavioral interventions and supports. Intervention in School and Clinic, 52(2), 122-128. doi:10.1177/1053451216636057

Ball, S. J. (2003). The teacher's soul and the terrors of performativity. Journal of Education Policy, 18(2), 215-228. doi:10.1080/0268093022000043065

Bergerson, A. A. (2003). Critical race theory and white racism: Is there room for white scholars in fighting racism in education? International Journal of Qualitative Studies in Education, 16(1), 51-63. doi:10.1080/0951839032000033527 
Brown, S. E. (2002). What is disability culture? Disability Studies Quarterly, 22, 34-50. doi: $10.18061 /$ dsq.v22i2.343

CAST (2011). Universal design for learning guidelines version 2.0. Wakefield, MA: Author.

Connor, D. J. (2013). Who "owns" dis/ability? The cultural work of critical special educators as insider-outsiders. Theory \& Research in Social Education, 41(4), 494-513. Retrieved from https://doi-org.proxy.ulib.uits.iu.edu/10.1080/00933104.2013.838741

doi:10.1080/00933104.2013.838741

Connor, D. J., \& Ferri, B. A. (2005). Integration and inclusion-a troubling nexus: Race, disability, and special education. The Journal of African American History, 90(1-2), 107127.107 doi:10.1086/jaahv90n1-2p

Corbett, J. \& Slee, R, (2000). An international conversation on inclusive education. In F. Armstrong, D. Armstrong, \& L. Barton (Eds.), Inclusive education: Policy, contexts and comparative perspectives (pp. 133-146). London: David Fulton.

Delgado, R. (1989). Storytelling for oppositionists and others: A plea for narrative. Michigan Law Review, 87(8), 2411-2441. doi:10.2307/1289308

Delgado, R., \& Stefancic, J. (2017). Critical race theory: An introduction. New York, NY: NYU Press.

Dudley-Marling, C., \& Gurn, A. (Eds.). (2010). The myth of the normal curve (Vol. 11). New York, NY: Peter Lang.

Education of All Handicapped Children Act of 1975. 
Engeström, Y. (2001). Expansive learning at work: Toward an activity theoretical reconceptualization. Journal of Education and Work, 14(1), 133-156. doi:10.1080/13639080123238

Engeström, Y. (1987). Learning by expanding: An activity-theoretical approach to developmental research. Helsinki: Orienta-Konsultit.

Engeström, Y., \& Sannino, A. (2010). Studies of expansive learning: Foundations, findings and future challenges. Educational Research Review, 5(1), 1-24. doi:10.1016/j.edurev.2009.12.002

Erevelles, N. (2000). Educating unruly bodies: Critical pedagogy, disability studies, and the politics of schooling. Educational Theory, 50(1), 25-47. doi:10.1111/j.1741-5446.2000.00025.x

Erevelles, N. (2014). Crippin' Jim Crow: Disability and the school-to-prison pipeline. In L. BenMoshe, Y. A. Davis, \& C. Chapman (Eds.), Disability Incarcerated: Imprisonment and disability in the United States and Canada (pp. 81-99). New York, NY: Palgrave Macmillan.

Ferri, B. A. (2009). Doing a (dis)service: Reimagining special education from a disability studies perspective. In W. Ayers, T. Quinn, \& D. Stovall (Eds.), Handbook of social justice in education (pp. 417-430). New York, NY: Routledge.

Ferri, B. A., \& Connor, D. J. (2005). Tools of exclusion: Race, disability, and (re) segregated education. Teachers College Record, 107(3), 453-474. doi:10.1111/j.1467-9620.2005.00483.x

Ford, D. Y., \& Toldson, I. (2015). Study on Black, Hispanic children in special ed wrong, regressive. Diverse voices in higher education. Retrieved from http://diverseeducation.com/article/76088/ 
Fraser, N. (2008). Scales of justice: Reimagining political space in a globalizing world. Cambridge, UK: Polity Press.

Goertzel, T., \& Fashing, J. (1981). The myth of the normal curve: A theoretical critique and examination of its role in teaching and research. Humanity and Society, 5(1), 14-31. doi: $10.1177 / 016059768100500103$

Graff, C. S., \& Kozleski, E. (2014). Calcifying sorting and segregating: Brown at 60. Multiple Voices for Ethnically Diverse Exceptional Learners, 14(2), 52-67.

Green, T. L., \& Dantley, M. E. (2013). The great white hope? Examining the white privilege and epistemology of an urban high school principal. Journal of Cases in Educational Leadership, 16(2), 82-92. Retrieved from https://doi-org.proxy.ulib.uits.iu.edu/10.1177/1555458913487038 doi: $10.1177 / 1555458913487038$

Gutiérrez, K. D., \& Rogoff, B. (2003). Cultural ways of learning: Individual traits or repertoires of practice. Educational Researcher, 32(5), 19-25. doi:10.3102/0013189X032005019

Holland, D., Lachicotte, D., Jr, Skinner, D. D., \& Cain, C. (1998). Identity and agency in cultural worlds. Cambridge, MA: Harvard University Press.

Individuals with Disabilities Education Act of 1997. P.L. 105-17, 20 U.S.C. § 1400 et seq. Individuals with Disabilities Education Act of 2004. P.L. 108-446.

Kauffman, J. M., \& Hung, L. Y. (2009). Special education for intellectual disability: Current trends and perspectives. Current Opinion in Psychiatry, 22(5), 452-456. https://doiorg.proxy.ulib.uits.iu.edu/10.1097/yco.0b013e32832eb5c3

doi:10.1097/YCO.0b013e32832eb5c3 
Kauffman, J. M., \& Badar, J. (2013). How we might make special education for students with emotional or behavioral disorders less stigmatizing. Behavioral Disorders, 39(1), 16-27. https://doi-org.proxy.ulib.uits.iu.edu/10.1177/019874291303900103 doi:10.1177/019874291303900103

Kozleski, E. B., \& Artiles, A. J. (2012). Technical assistance as inquiry: Using activity theory methods to engage equity in educational practice communities. In S. Steinberg \& G. Canella (Eds.), Handbook on critical qualitative research (pp. 431-445). New York, NY: Peter Lang.

Kozleski, E. B., \& Artiles, A. J. (2015). Mediating systemic change in educational systems through sociocultural methods. In P. Smeyers, D. Bridges, M. Griffiths, \& N. Burbules (Eds.), International handbook of interpretation in educational research methods (pp. 805-822). New York: Springer.

Kozleski, E. B., \& Zion, S. (2006). Preventing disproportionality by strengthening district policies and procedures - An assessment and strategic planning process. Tempe, AZ: National Center for Culturally Responsive Education Systems (NCCRESt).

Kroesbergen, E. H., \& Van Luit, J. E. (2003). Mathematics interventions for children with special educational needs: A meta-analysis. Remedial and Special Education, 24(2), 97-114. doi:10.1177/07419325030240020501

Leonardo, Z. (2010). Whiteness studies in education: Making the familiar strange. Equity Alliance Blog. Tempe: AZ: Equity Alliance at ASU. Retrieved from http://www.niusileadscape.org/bl/whiteness-studies-and-education-making-the-familiar-strangeby-zeus-leonardo/ 
Leonardo, Z., \& Broderick, A. A. (2011). Smartness as property: A critical exploration of intersections between whiteness and disability studies. Teachers College Record, 113, 22062232.

Lewis, T. A. (2017). Emmett Till \& the pervasive erasure of disability in conversations about white supremacy \& police violence. Retrieved from https://www.talilalewis.com/blog/emmetttill-disability-erasure

McCall, Z., \& Skrtic, T. (2009). Intersectional needs politics: A policy frame for the wicked problem of disproportionality. Multiple Voices for Ethnically Diverse Exceptional Learners, 11(2), 3-23.

Mehan, H. (1996). Beneath the skin and between the ears: A case study in the politics of representation. In S. Chaiklin \& J. Lave (Eds.), Understanding practice: Perspectives on activity and context (pp. 241-268). Cambridge, MA: Cambridge University Press.

Moore, L. F. (2016). Black disabled art history. San Francisco, CA: Xóchitl Justice Press.

Morgan, P. L., Farkas, G., Hillemeier, M. M., Mattison, R., Maczuga, S., Li, H., \& Cook, M. (2015). Minorities are disproportionately underrepresented in special education: Longitudinal evidence across five disability conditions. Educational Researcher, 44(5), 278-292. doi:10.3102/0013189X15591157

Mulligan, E. M., \& Kozleski, E. B. (2009, October). A framework for culturally responsive cognitive coaching in schools. Retrieved from the National Institute for Urban School Improvement website: http://www.niusileadscape.org/docs/FrameworkCulturally_Web 
National Center on Response to Intervention (2010, April). Essential components of RTI-A closer look at response to intervention. Washington, DC: Author. Retrieved from http://www.rti4success.org/sites/default/files/rtiessentialcomponents_042710.pdf

Oliver, M. (1996). Understanding disability: From theory to practice. New York, NY: St. Martin’s Press.

Paris, D. (2012). Culturally sustaining pedagogy: A needed change in stance, terminology, and practice. Educational Researcher, 41(3), 93-97. doi:10.3102/0013189X12441244

Public Law 94-142 (1975). Individuals with Disabilities Education Act, 20 U.S.C. $§ 1400$ et seq. (1997).

Roth, W. M. (2012). Cultural-historical activity theory: Vygotsky's forgotten and suppressed legacy and its implication for mathematics education. Mathematics Education Research Journal, 24(1), 87-104. doi:10.1007/s13394-011-0032-1

Sackler, H. (1968). The Great White Hope. New York, NY: Dial.

Shakespeare, T. (2006). The social model of disability. The Disability Studies Reader, 2, 197204.

Skelton, S. M. (2019). Situating my positionality as a Black woman with a dis/ability in the provision of equity-focused technical assistance: A personal reflection. International Journal of Qualitative Studies in Education.

Skiba, R., Artiles, A. J., Kozleski, E. B., Losen, D., \& Harry, B. (2016). Risks and consequences of over simplifying educational inequities: A response to Morgan et al. (2015). Educational Researcher, 45(3), 221-225. doi:10.3102/0013189X16644606 
Sullivan, A. L., \& Artiles, A. J. (2011). Theorizing racial inequity in special education: Applying structural inequity theory to disproportionality. Urban Education, 46(6), 1526-1552. doi:10.1177/0042085911416014

Tan, P., \& Thorius, K. A. K. (2018a). Toward equity in education for students with dis/abilities: A case study of professional learning. American Educational Research Journal. doi:10.3102/0002831218811906

Tan, P., \& Thorius, K. A. K. (2018b). En/countering inclusive mathematics education: A case of professional learning. Mathematics Teacher Educator, 6 (2), 52-67. doi:

10.5951/mathteaceduc.6.2.0052

Thorius, K. A. K. (2015). High-leverage strategies for addressing special education disproportionality. Green Bay, WI: Wisconsin Department of Public Instruction Annual Disproportionality Technical Assistance Network Conference.

Thorius, K. A. K. (2016). Stimulating artifact-mediated tensions in special education teachers' figured world: An approach toward inclusive education. International Journal of Inclusive Education, 20(12), 1326-1343. doi:10.1080/13603116.2016.1168877

Thorius, K. A. K. (2016b). Culturally responsive positive behavior interventions \& supports: School planning, assessment, \& improvement tool. Bethesda, MD: Mid-Atlantic Equity Consortium.

Thorius, K. A. K. (2017). Countering problematic legacies of the practice of psychology in schools: From "gatekeeper" to "inclusive education activist". Boise, Idaho: Idaho Association of School Psychologists Annual Meeting. 
Thorius, K. A. K., \& Maxcy, B. D. (2015). Critical practice analysis of special education policy: An RTI example. Remedial \& Special Education, 36, 115-124.

doi: $10.1177 / 0741932514550812$

Thorius, K. A. K., \& Scribner, S. M. P. (2013). Teacher learning in urban schools. In E. B. Kozleski \& K. A. K. Thorius (Eds.), Ability, equity, and culture: Sustaining inclusive urban education reform (pp. 134-150). New York, NY: Teachers College Press.

Thorius, K. A. K., \& Stephenson, J. (2012). Racial and ethnic disproportionality in special education. In A. L. Noltemeyer \& C. Mcloughlin (Eds.), Disproportionality in education and special education: A guide to creating more equitable learning environments (pp. 25-44). Springfield, IL: Charles C. Thomas.

Thorius, K. A. K., \& Waitoller, F. R. (2017). Strategic coalitions against exclusion at the intersection of race and disability_A rejoinder. Harvard Educational Review, 87(2), 251-257. Retrieved from https://doi-org.proxy.ulib.uits.iu.edu/10.17763/1943-5045-87.2.251 doi:10.17763/1943-5045-87.2.251

Thorius, K. A. K., Maxcy, B. D., \& Nguyen, T. S. T. (2015). Equity-focused technical assistance in the transition of United States public schools. Budapest, Hungary: European Educational Research Association Annual Meeting.

Thorius, K. A. K., Maxcy, B. D., Macey, E., \& Cox, A. (2014). A critical practice analysis of Response to Intervention appropriation in an urban school. Remedial and Special Education, 35, 287-299. doi:10.1177/0741932514522100 
Thorius, K. A. K., Novak, B., Faasuamalie, E., Bischoff, J., Skelton, S. M., \& Coomer, M. N. (2018). Expansive learning in a technical assistance partnership focused on literacy for students with disabilities. New York, NY: American Educational Research Association Annual Meeting.

Thorius, K. A. K., Tan, P. (2015). Expanding analysis of educational debt: Considering intersections of race and ability. In D. Connor, B. Ferri, \& S. A. Annamma (Eds.), DisCrit: Critical conversations across race, class, \& dis/ability. New York, NY: Teachers College Press.

Valencia, R. R. (1997). Conceptualizing the notion of deficit thinking. In R. R. Valencia (Ed.), The evolution of deficit thinking: Educational thought and practice (pp. 1-12). Bristol, PA: Falmer.

Voulgarides, C. K., Fergus, E., \& Thorius, K. A. K. (2017). Pursuing equity: Disproportionality in special education and the reframing of technical solutions to address systemic inequities. Review of Research in Education, 41, 61-87. doi:10.3102/0091732X16686947

Waitoller, F. R., \& Kozleski, E. B. (2013). Understanding and dismantling barriers for partnerships for inclusive education: A cultural historical activity theory perspective. International Journal of Whole Schooling, 9(1), 23-42.

Waitoller, F. R., \& Thorius, K. A. K. (2016). Cross-pollinating culturally sustaining pedagogy with universal design for learning: Toward an inclusive pedagogy that accounts for student dis/ability. Harvard Educational Review, 86(3), 366-389. doi:10.17763/1943-5045-86.3.366

Waitoller, F. R., Artiles, A. J., \& Cheney, D. A. (2010). The miner's canary: A review of overrepresentation research and explanations. The Journal of Special Education, 44(1), 29-49. doi:10.1177/0022466908329226 
Ware, L. (Ed.). (2004). Ideology and the politics of (in)exclusion. New York, NY: Peter Lang.

Workman, T. (1918, August 30). Better Babies diploma [digital image]. Retrieved from http://jtenlen.drizzlehosting.com/walewis/workman2.jpg 


\section{Figures}

Figure 1. Special education teacher t-shirt. Retrieved from

www.Keepitschool.com/products/special-education-teacher-someone-

special variant $=6107737349$

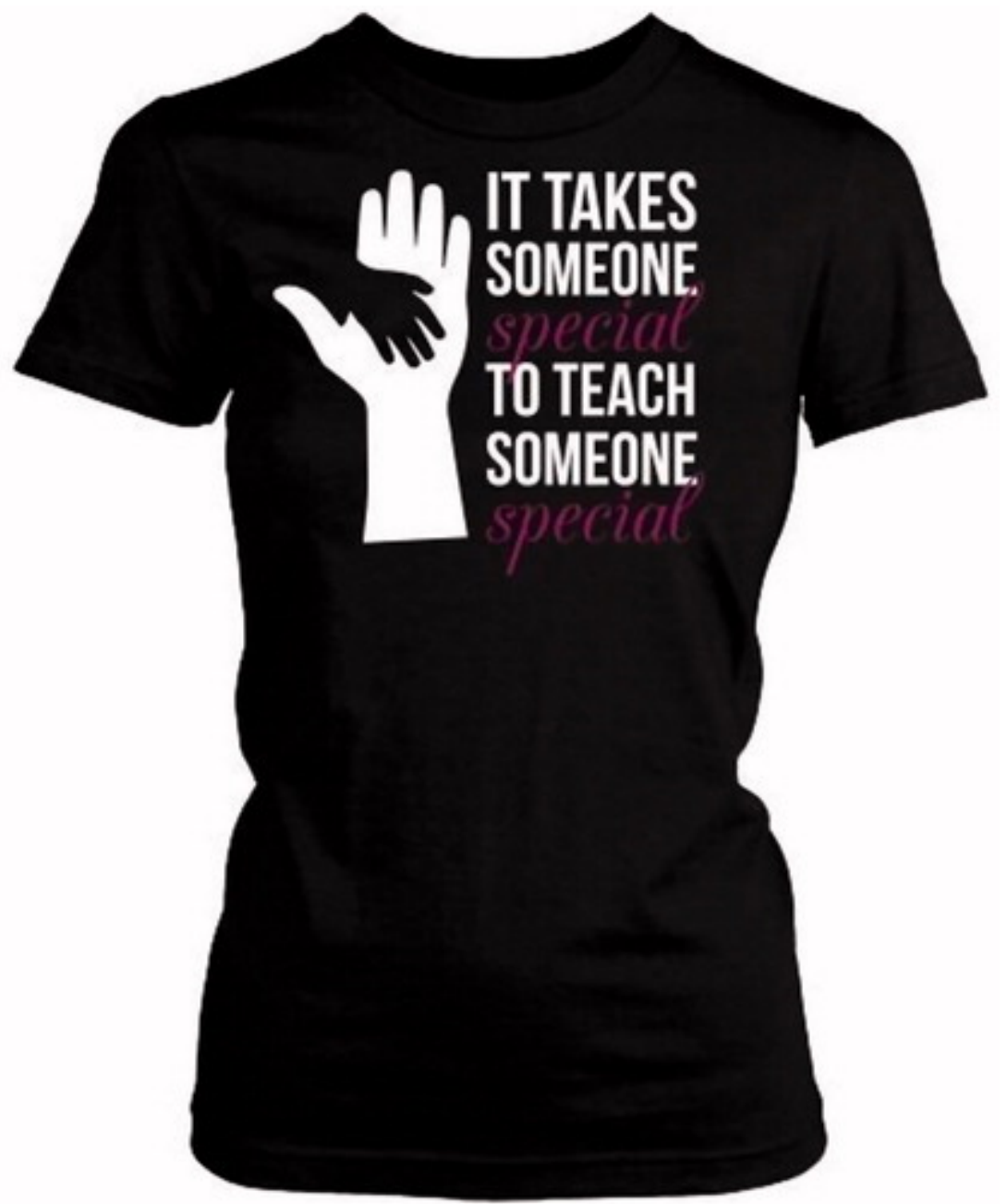


Figure 2. Steps of expansive learning cycle. From Engeström, Y., Virkkunen, J., Helle, M., Pihlaja, J., \& Poikela, R. (1996). The change laboratory as a tool for transforming work. Lifelong Learning in Europe, 1(2), 10-17. Used with permission.

\section{Consolidating the new practice}

6. Reflecting on the process

5. Implementing

the new model

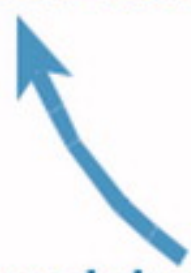

4. Examining the new model
1. Need state / ethnography

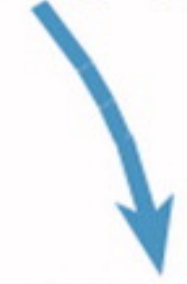

2. Analyzing contradictions

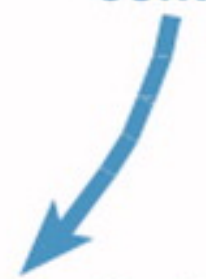

3. Designing a new model 
Figure 3. Slide from professional learning session (Thorius, 2017).

"Deviations more or less great from the mean have constituted ugliness in body as well as in morals and a state of sickness with regard to the constitution " (Quetelet, cited in Porter, 1986, p, 103).

\section{IQ Normal Curve}

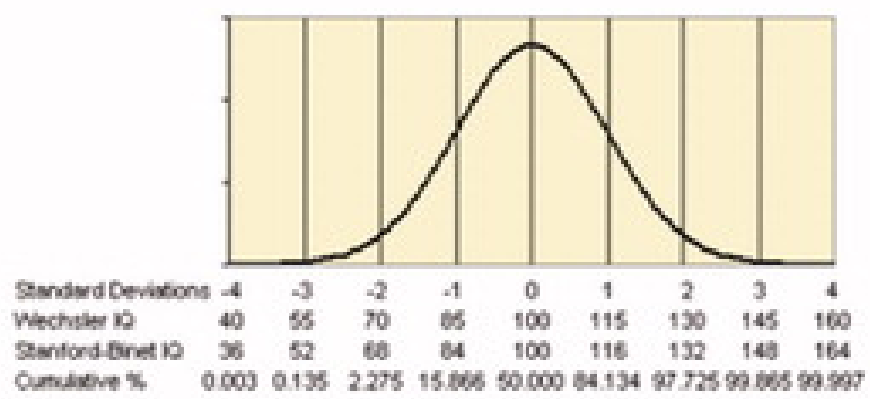

"This is what I am driving at-that analogy clearly -how there must be a fairly constant average mental capacity in the inhabitants of British Isle" and that deviations from that average-upwards towards genius, and downwards towards stupidity -must follow the law that governs deviations from all true averages.

(Galton,1869, cited in MacKenzie, 2981, p. 32) 